\title{
Analisis Performansi Dan Efisiensi Cloud Computing Pada Sistem Perbankan
}

\author{
I K. Adi Kurniawan ${ }^{1}$, N. Putra Sastra ${ }^{2}$, M. Sudarma ${ }^{3}$ \\ Submission: 27-10-2019, Accepted: 25-11-2019
}

\begin{abstract}
The use of physical servers for Bank Mandiri branch office's operations has several shortcomings; such as exorbitant server procurement costs, limitation on upgrading parts, high maintenance cost, requirement for land procurement, and excessive electricity consumption. An alternative to that is cloud computing technology based on virtualization using the ROCCA adoption method. In this study, cloud computing was implemented with Microsoft Hyper-V virtualization to run Bank Mandiri branch's operational applications. The result of performance and cost efficiency tests of cloud computing is then compared to that of physical servers. The test results demonstrate that the ROCCA method can be utilized for cloud computing adoption in the banking sector. Overall, physical server CPU (36\% score) works 4 times better than cloud server (9\% score). However, cloud server memory (score 50\%) works 1.4 times faster than physical servers (score 35\%). The performance of the cloud server hard disk (52\% score) is $\mathbf{1 . 1}$ times better than the physical server $(48 \%$ score). In terms of access speed, physical server is faster as it reaches a bandwidth of 94.9 Mbits/sec, while cloud server reaches $94.1 \mathrm{Mbits} / \mathrm{sec}$. As to investment efficiency; the cost of a cloud server for one year period is lower than that of a physical server. However, for a period of five years and above; the cloud server costs are higher than that of physical servers.
\end{abstract}

Abstrak- Penggunaan server fisik untuk operasional kantor cabang Bank Mandiri memiliki beberapa kekurangan, yaitu biaya pengadaan server yang tinggi, keterbatasan upgrade part, biaya maintainance, kebutuhan lahan dan konsumsi listrik. Alternatif yang bisa digunakan adalah teknologi cloud computing berbasis virtualisasi dengan metoda adopsi ROCCA. Pada penelitian ini implementasi cloud computing menggunakan virtualisasi Microsoft Hyper-V. Selanjutnya dilakukan komparasi performansi dan efisiensi biaya yang dibandingkan dengan implementasi server fisik. Hasil pengujian menunjukkan metoda ROCCA dapat digunakan untuk adopsi cloud computing pada sektor perbankan. Performansi CPU server fisik (skor $36 \%$ ) bekerja 4 kali lebih baik daripada server cloud (skor 9\%). Performansi memori server cloud (skor 50\%) bekerja 1,4 kali lebih cepat daripada server fisik (skor 35\%). Sedangkan performansi disk server cloud (skor 52\%) lebih cepat 1,1 kali daripada server fisik (skor 48\%). Pada aspek kecepatan akses, server fisik lebih cepat dengan bandwidth 94,9 Mbits/detik, sedangkan server cloud 94,1 Mbits/detik. Dari sisi efisiensi investasi, selama jangka waktu satu tahun biaya server cloud lebih rendah daripada server fisik. Namun untuk jangka waktu lima tahun keatas, biaya server cloud lebih tinggi daripada server fisik.

\footnotetext{
${ }^{1}$ Mahasiswa, Magister Teknik Elektro, Pasca Sarjana Universitas Udayana e-mail: les.moines@gmail.com)

2, 3 Staff pengajar Magister Teknik Elektro, Program Pasca Sarjana Universitas Udayana, Jln. PB Sudirman, Denpasar, Bali (telp: 0361-239599; e-mail: ${ }^{2}$ putra.sastra@unud..ac.id, msudarma@unud.ac.id)
}

I K Adi Kurniawan dkk: Analisis Performansi dan Efisiensi ...
Saat ini operasional perbankan di kantor cabang Bank Mandiri menggunakan aplikasi desktop dengan server yang ditempatkan pada masing-masing kantor cabang. Arsitektur berbasis server fisik ini memiliki kekurangan, yaitu:

1. Biaya pengadaan server tinggi dan butuh waktu lama.

2. Kebutuhan setiap kantor cabang berbeda namun spesifikasi server sama untuk seluruh kantor cabang. Di sisi lain terdapat kendala skalibilitas dimana untuk kebutuhan upgrade perlu proses pengadaan kembali yang memakan waktu.

3. Perlu adanya maintainance server secara berkala, seperti restart mesin dan cleansing data.

4. Dibutuhkan lokasi khusus untuk ruang server dengan standar kelengkapan ruang server serta sumber daya listrik.

Alternatif solusi untuk kendala tersebut adalah dengan implementasi cloud computing. Cloud computing merupakan tren baru dibidang komputasi terdistribusi dimana berbagai pihak dapat mengembangkan aplikasi dan layanan berbasis Service Oriented Architecture di jaringan internet [1]. Cloud menjadikan internet sebagai pusat server untuk data dan aplikasi [2]. IaaS (Infrastructure as a Service) merupakan layanan cloud untuk memenuhi kebutuhan infrastruktur seperti virtualisasi, hardware server, media penyimpanan, dan jaringan [3]. Selain memberikan efisiensi bagi perusahaan, cloud mampu mengingkatkan produktifitas kerja [4]. Cloud computing juga mampu memberikan efisiensi dalam hal manajemen sumber daya (fleksibilitas dan skalabilitas) [5]. Semakin banyak industri yang beralih ke teknologi cloud karena secara efisien mampu meningkatkan kualitas layanan dengan menekan biaya berlebih, mengurangi downtime, dan pengembangan infrastruktur secara otomasi [6]. Secara umum, cloud computing memberikan manfaat bagi ekonomi, organisasi, dan sosial [7].

Penerapan teknologi informasi (TI) pada sektor perbankan utamanya dipengaruhi oleh bertambahnya kebutuhan nasabah serta peningkatan volume transaksi. Industri perbankan sangat intensif dalam menggunakan TI sehingga sangat bergantung pada perkembangan TI tersebut [8]. Bank merupakan segmen penting dalam area bisnis yang menjadi target cloud computing. [9] Bank yang menggunakan cloud computing memiliki posisi yang lebih baik untuk menanggapi ketidakpastian ekonomi dan sistem keuangan global yang saling berhubungan [10]. Cloud computing dapat menghemat biaya operasional yang dikeluarkan karena semakin banyaknya pilihan layanan cloud computing oleh berbagai vendor [12]. Ada beberapa model pengembangan cloud computing yang dapat diterapkan pada bidang perbankan, yaitu private cloud, community cloud, public cloud, dan hybrid cloud. Namun demikian model yang paling sesuai adalah private cloud [13]. Private cloud memberikan manfaat p-ISSN:1693 - 2951; e-ISSN: 2503-2372 
yang lebih baik dari sisi keamanan dan privasi. Pengembangan private cloud dilakukan secara eksklusif oleh organisasi dan hanya dapat diakses oleh internal organisasi atau rekanan yang diberikan kewenangan [14].

Penting bagi perusahaan untuk memahami bahwa implementasi cloud computing bukan hanya terkait dengan hal teknis, namun juga melibatkan tantangan lain berupa kendala biaya, kesiapan pengguna, dan organisasi [15]. Penelitian lain menyebutkan terdapat empat fokus area yang harus diperhatikan sebelum melakukan adopsi cloud computing, yaitu aspek teknikal, organisasi, biaya, dan lingkungan [16]. Sebuah organisasi yang akan menerapkan cloud computing perlu menjalani 5 tahap (fase) adopsi, yaitu tahap analysis, planning, adoption, migration, dan management [17] sebagaimana ditampilkan pada gambar 1 berikut.

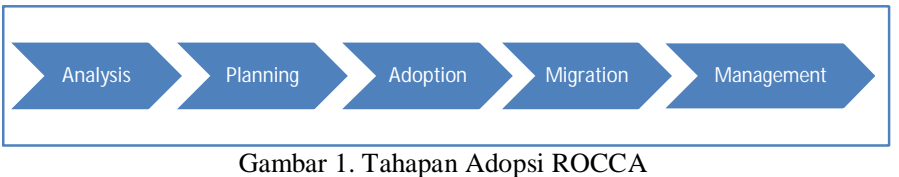

Tahap analysis adalah tahapan untuk mengidentifikasi kebutuhan pemakai, kondisi organisasi, kebijakan dan regulasi serta aspek lain yang memengaruhi keputusan organisasi dalam menerapkan teknologi informasi. Pada fase ini dilakukan dua kegiatan yaitu pengumpulan data dan analisa data [18]. Pada tahap planning, ditentukan tolok ukur permasalahan keamanan, hukum dan kepatuhan. Tolok ukur ini harus dapat merefleksikan best practice, kebijakan, dan standar dalam organisasi dan bagaimana ini semua dapat dicapai setelah migrasi ke cloud computing. Tahap adoption merupakan persiapan kebutuhan infrastruktur baik hardware dan software. Pada tahap migration dilakukan pemindahan data ke server cloud. Tahap management meliputi serah terima dengan user, kesepakatan service level agreement, jasa support serta dokumentasi.

\section{Virtualisasi}

Virtualisasi merupakan teknologi penggerak dibelakang cloud computing [19]. Dengan virtualisasi, pengguna layanan cloud computing dapat dengan mudah melakukan upgrade kapasitas server [20]. Terdapat dua pendekatan virtualisasi [21], yaitu:

1. Full Virtualization

Seluruh sistem komputer host dibuat dalam kontruksi software yang dapat dieksekusi oleh sistem operasi guest dimana setiap perintah diterjemahkan menjadi instruksi biner.

2. Para Virtualization

Terdapat modifikasi pada sistem operasi guest berupa penyesuaian kernel sehingga permintaan alokasi hardware tidak membutuhkan translasi ke dalam instruksi biner.

\section{Metode Penelitian}

Pada penelitian ini, dibangun dua infrastruktur server kantor cabang Bank Mandiri, yaitu server fisik sebagaimana kondisi semula dan cloud computing yang berbasis virtualisasi menggunakan hypervisor Windows Hyper-V dengan metode adopsi Roadmap for Cloud Computing Adoption (ROCCA).

Metode ROCCA diawali dengan tahap analysis untuk pengumpulan data melalui wawancara dengan pegawai Bank Mandiri, observasi di kantor cabang untuk mendata perangkat TI, aplikasi yang digunakan, serta dokumen tentang regulasi, standar dan kebijakan yang berlaku. Analisis juga dilakukan pada penyedia layanan cloud computing di Indonesia dan top leader global. Tahap planning merupakan tahap perancangan yang meliputi pemilihan teknologi virtualisasi serta anggaran yang dibutuhkan. Hal krusial yang juga diputuskan pada tahap planning adalah penentuan aplikasi yang akan dimigrasi. Tahap selanjutnya adalah adoption, yaitu mempersiapkan semua kebutuhan insfrastruktur, meliputi kebutuhan hardware dan software seperti sistem operasi, virtual machine manager, aplikasi database, dan aplikasi operasional kantor cabang (Branch Delivery System). Tahap migration merupakan inti dari adopsi arsitektur cloud, karena pada tahap ini dilakukan pemindahan data dari server fisik ke server cloud. Pada tahap management dilakukan pengujian untuk memastikan sistem berjalan normal sebagaimana pada saat sebelum migrasi. Topologi jaringan server cloud ditunjukkan pada gambar 2 berikut.

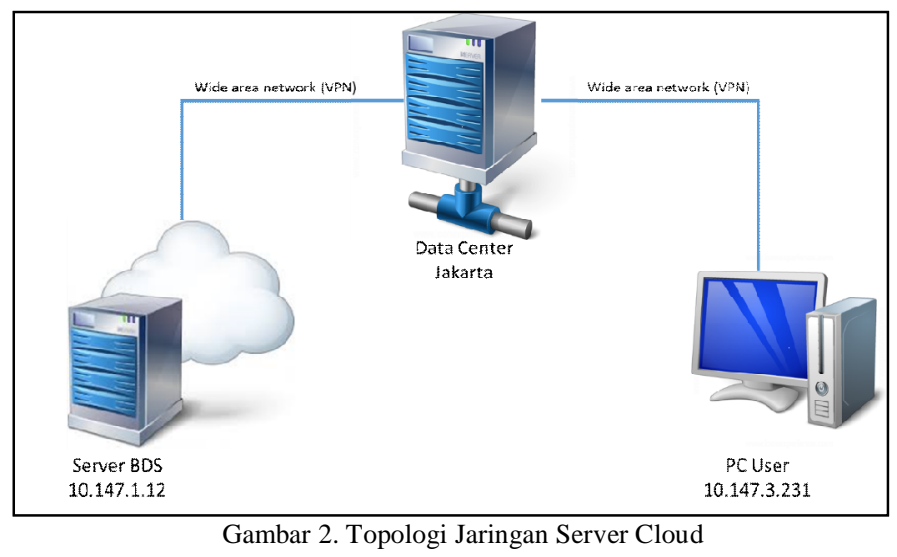

Setelah deployment server cloud dan server fisik, selanjutnya dilakukan komparasi performansi server cloud dengan fisik, yang meliputi performansi CPU, memory, harddisk menggunakan aplikasi passmark dan kecepatan koneksi menggunakan aplikasi iperf. Pada pengujian performansi CPU, memory, dan harddisk, nilai utilisasi berupa persentase yang diperoleh dari perbandingan skor yang dicapai dengan nilai best practise yang sudah ditentukan oleh passmark, dengan formula sebagai berikut:

$$
\text { nilai utilisasi }=\frac{\text { score pengujian }}{\text { nilai best practise }} \times 100 \%
$$

Selain pengukuran performansi, juga dilakukan pengukuran efisiensi investasi terhadap implementasi server cloud dan server fisik berdasarkan nilai investasinya, meliputi biaya 
pengadaan perangkat, Lisensi sistem operasi, Biaya catudaya, dan Inflasi.

\section{HASIL DAN PEMBAHASAN}

A. Implementasi ROCCA

1. Tahap Analysis

Secara topologi, saat ini server kantor cabang Bank Mandiri terhubung dengan client melalui koneksi Local Area Network (LAN). Sedangkan dari server ke server core banking di data center terhubung melalui koneksi wide area network. Topologi server fisik ditampilkan pada gambar 3 berikut.

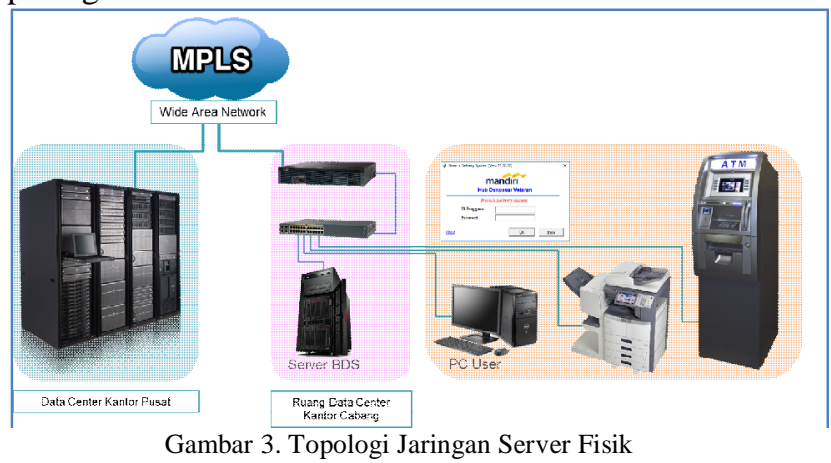

Perangkat hardware dan software yang digunakan di kantor cabang tergantung dengan masa pakai yang terbatas. Meskipun secara operasional masih bisa digunakan, perangkat tersebut harus diremajakan karena masa support-nya telah habis. Server, PC, router, switch, modem, dan printer memiliki usia teknis selama lima tahun.

Penelitian terhadap penyedia layanan cloud computing dilakukan pada beberapa vendor sebagaimana ditampilkan pada table I berikut.

TABEL I

SPESIFIKASI SERVER KANTOR CABANG

\begin{tabular}{|l|c|l|r|}
\hline & $\begin{array}{c}\text { Service } \\
\text { Level } \\
\text { Guarantee }\end{array}$ & $\begin{array}{c}\text { Data } \\
\text { Center di } \\
\text { Indonesia }\end{array}$ & $\begin{array}{c}\text { Harga / bulan } \\
\text { (Rp) }\end{array}$ \\
\hline $\begin{array}{l}\text { Alibaba } \\
\text { Cloud }\end{array}$ & $99.95 \%$ & Ya & 1.948 .483 \\
\hline Zettagrid & $99.90 \%$ & Ya & 2.761 .000 \\
\hline $\begin{array}{l}\text { Amazon } \\
\text { Web } \\
\text { Services }\end{array}$ & $99.99 \%$ & $\begin{array}{l}\text { Sedang } \\
\text { dibangun }\end{array}$ & 3.305 .318 \\
\hline $\begin{array}{l}\text { Windows } \\
\text { Azure }\end{array}$ & $99.95 \%$ & Tidak & 1.610 .560 \\
\hline $\begin{array}{l}\text { Google } \\
\text { Cloud } \\
\text { Platform }\end{array}$ & $99.99 \%$ & $\begin{array}{l}\text { Sedang } \\
\text { dibangun }\end{array}$ & 4.185 .300 \\
\hline
\end{tabular}

Mempertimbangkan profil masing-masing penyedia jasa cloud computing dilihat dari sisi service level guarantee, dukungan layanan, konsumen, harga, serta mengacu pada peraturan OJK NOMOR 38

I K Adi Kurniawan dkk: Analisis Performansi dan Efisiensi ...
/POJK.03/2016 Bab IV bagian kedua tentang penempatan sistem elektronik pada pusat data dan/atau pusat pemulihan bencana, maka rekomendasi jasa cloud computing yang digunakan adalah Alibaba Cloud. Alibaba Cloud memberikan service level guarantee sebesar $99.95 \%$ dengan proses recovery sepenuhnya dilakukan secara otomasi. Fitur lain yang disediakan oleh Alibaba Cloud yaitu garansi packet loss jaringan yang hanya sebesar $0.0001 \%$, penggunaan virtual switch yang mampu menekan angka latency network sebesar $66 \%$ serta layanan proteksi data yang menggunakan triplicate technology, yaitu konsep back up data file dengan menempatkan data pada tiga server yang berbeda

2. Tahap Planning

Server cloud dibangun pada sebuah perangkat server Lenovo Thinkserver TS 460 dengan virtual machine manager (VMM) Microsoft Hyper-V Server 2016. Aplikasi yang dimigrasi pada penelitian ini adalah BDS, karena hanya aplikasi tersebut yang servernya akan beralih ke arsitektur cloud. Sedangkan aplikasi selain BDS bersifat web based sehingga tidak terdampak dengan migrasi kantor cabang ke cloud.

3. Tahap Adoption

Pada tahap adoption dilakukan deployment server cloud dengan spesifikasi hardware dan software seperti pada tabel II.

TABEL II

KEBUTUHAN HARDWARE DAN SOFTWARE

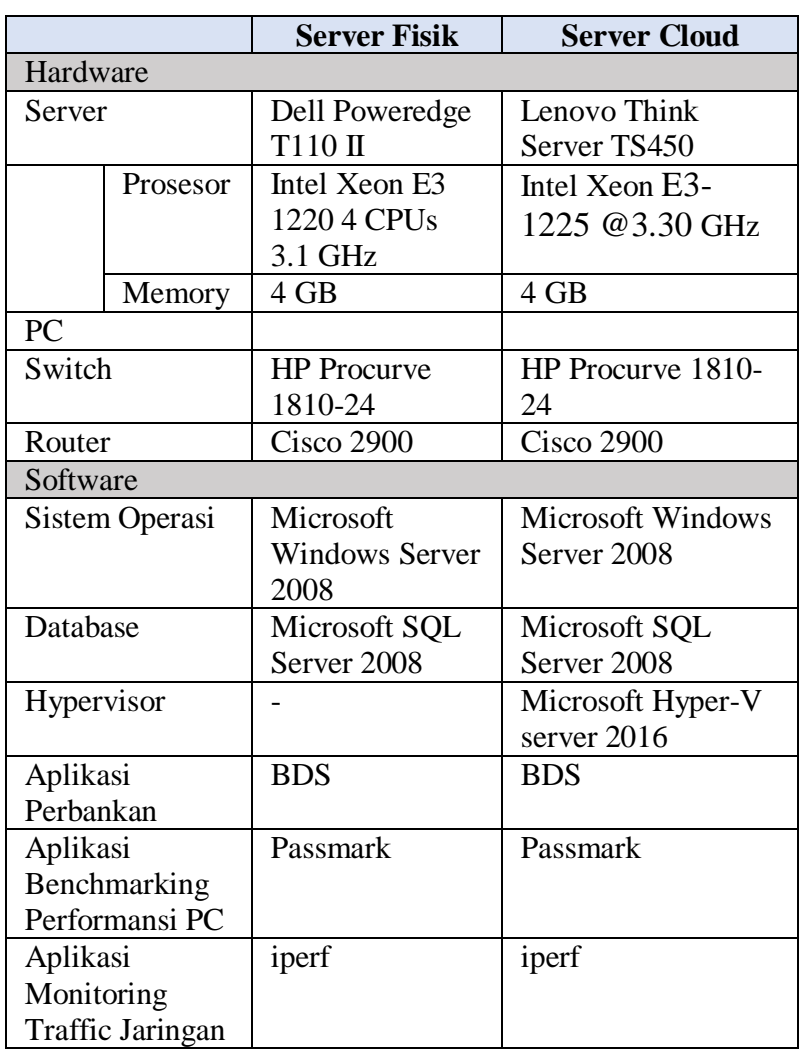

p-ISSN:1693 - 2951; e-ISSN: 2503-2372 
Deplopyment server cloud dimulai dengan preparasi BIOS untuk mengaktifkan fitur virtualisasi pada host server dan konfigurasi harddisk menggunakan Redundant Array of Independent Disks level 0 untuk memaksimalkan kapasitas harddisk serta akses yang lebih cepat. Dilanjutkan dengan instalasi dan konfigurasi Microsoft Hyper-V Server 2016, meliputi pengaturan domain, computer name, remote management, dan pengaturan jaringan. Proses berikutnya adalah instalasi sistem operasi virtual yaitu Microsoft Windows Server 2008, database Microsoft SQL Server 2008, dan aplikasi Branch Delivery System.

4. Tahap Migration

Pada tahap migration dilakukan restore database yang sebelumnya di-export dari server fisik sebagaimana ditunjukkan pada gambar 4 berikut. Pada tahap ini juga dilakukan migrasi data dan konfigurasi aplikasi Branch Delivery System.

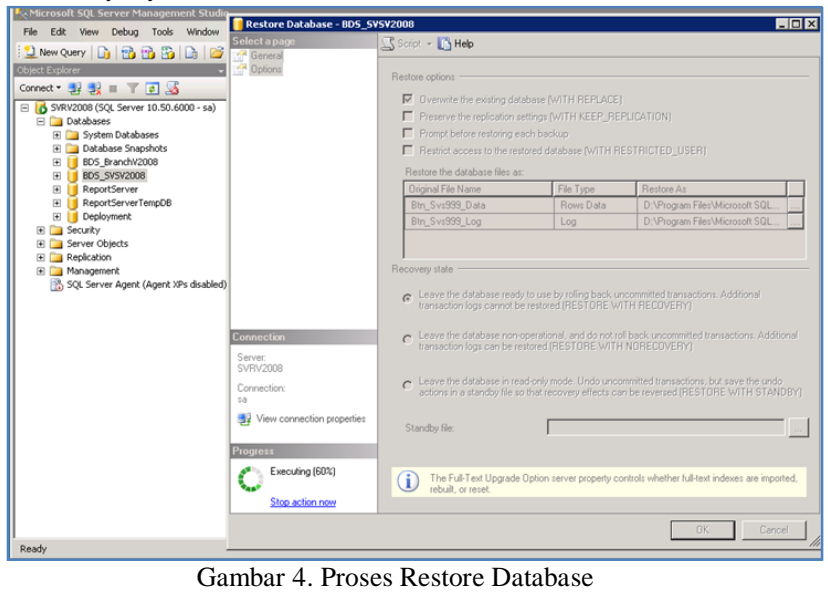

\section{Tahap Management}

Pada tahap management dilakukan pengujian dengan menjalankan aplikasi Branch Delivery System, sebagaimana ditampilkan pada gambar 5 berikut.

Branch Delivery System (Yersi 11.00.00) X

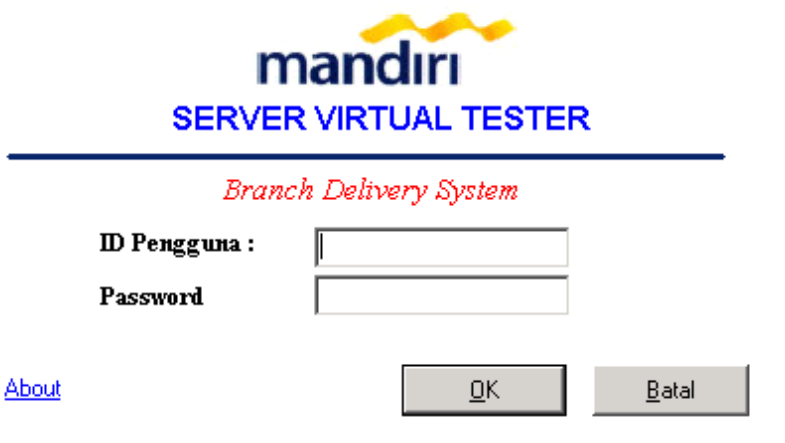

Gambar 5. Tampilan Aplikasi BDS pada Server Cloud

B. Pengujian Performansi

Pengujian performansi meliputi utilitas CPU, memory, harddisk dengan menggunakan aplikasi passmark dan network menggunakan iperf. Parameter pengujian performansi CPU, memory, dan harddisk disajikan pada tabel III, tabel IV dan tabel V sebagai berikut.

TABEL III

PARAMETER PENGUJIAN CPU

\begin{tabular}{|c|c|c|}
\hline No & Parameter & Keterangan \\
\hline 1 & Single Threaded & $\begin{array}{l}\text { Pengujian kombinasi tes Floating } \\
\text { Point, Sorting, dan Compression. }\end{array}$ \\
\hline 2 & Sorting & $\begin{array}{l}\text { Pengujian mengurutkan array } \\
500.000 \text { string acak dengan panjang } \\
\text { masing-masing } 25 \text { karakter. }\end{array}$ \\
\hline 3 & Physics & $\begin{array}{l}\text { Pengujian berbasis Bullet Physics } \\
\text { Engine }\end{array}$ \\
\hline 4 & Encryption & $\begin{array}{l}\text { Pengujian enkripsi menggunakan } \\
\text { library Crypto++. Tes ini dipecah } \\
\text { menjadi empat tahap dengan masing- } \\
\text { masing tahap menggunakan algoritma } \\
\text { TwoFish, AES, Salsa20 \& SHA256 } \\
\text { dan algoritma Hashing. }\end{array}$ \\
\hline 5 & Compression & $\begin{array}{l}\text { Tes kompresi dengan algoritma } \\
\text { pengkodean Adaptif berdasarkan } \\
\text { source code "Arithmetic Coding for } \\
\text { Compression Data". }\end{array}$ \\
\hline 6 & Multimedia & $\begin{array}{l}\text { Pengujian pemrosesan informasi } \\
\text { berupa image, audio, dan video. }\end{array}$ \\
\hline 7 & Prime numbers & Pengujian pencarian bilangan prima \\
\hline 8 & Floating Point & $\begin{array}{l}\text { Pengujian kalkulasi menggunakan } \\
\text { variabel floating point }\end{array}$ \\
\hline 9 & Integer & $\begin{array}{l}\text { Pengujian kalkulasi menggunakan } \\
\text { variabel integer. }\end{array}$ \\
\hline 10 & CPU Mark & $\begin{array}{l}\text { Merupakan nilai rata-rata atas hasil } \\
\text { pengukuran terhadap } \\
\text { parameter }\end{array}$ \\
\hline
\end{tabular}

TABEL IV

PARAMETER PENGUJIAN MEMORY

\begin{tabular}{|c|c|c|}
\hline No & Parameter & Keterangan \\
\hline 1 & $\begin{array}{l}\text { Memory } \\
\text { Threaded }\end{array}$ & $\begin{array}{l}\text { Pengukuran waktu untuk membaca } \\
\text { blok memori yang besar sehingga } \\
\text { tidak bisa disimpan dalam cache. }\end{array}$ \\
\hline 2 & Latency & $\begin{array}{l}\text { Pengukuran waktu yang diperlukan } \\
\text { oleh satu byte memori untuk ditransfer } \\
\text { ke CPU. }\end{array}$ \\
\hline 3 & $\begin{array}{l}\text { Available } \\
\text { RAM }\end{array}$ & $\begin{array}{l}\text { Pengukuran alokasi memori yang } \\
\text { tersedia untuk digunakan oleh } \\
\text { aplikasi. }\end{array}$ \\
\hline 4 & Memory Write & $\begin{array}{l}\text { Pengukuran waktu yang diperlukan } \\
\text { untuk menulis informasi ke memory }\end{array}$ \\
\hline 5 & $\begin{array}{l}\text { Memory Read } \\
\text { Uncached }\end{array}$ & $\begin{array}{l}\text { Pengukuran waktu yang dibutuhkan } \\
\text { untuk membaca blok memori yang } \\
\text { besar sehingga tidak bisa disimpan } \\
\text { dalam cache. }\end{array}$ \\
\hline 6 & $\begin{array}{l}\text { Memory Read } \\
\text { Cached }\end{array}$ & $\begin{array}{l}\text { Pengukuran waktu yang dibutuhkan } \\
\text { untuk membaca blok memori yang } \\
\text { kecil. Blok tersebut cukup kecil untuk } \\
\text { disimpan sepenuhnya dalam cache. }\end{array}$ \\
\hline 7 & $\begin{array}{l}\text { Database } \\
\text { Operations }\end{array}$ & $\begin{array}{l}\text { Pengukuran kemampuan memori } \\
\text { dalam mempertahankan struktur data } \\
\text { pada database berbasis C++ STL } \\
\text { containers. }\end{array}$ \\
\hline 8 & Memory mark & $\begin{array}{lrr}\text { Merupakan } & \text { nilai rata-rata } & \text { atas hasil } \\
\text { pengukuran } & \text { terhadap } & \text { seluruh }\end{array}$ \\
\hline
\end{tabular}


parameter

TABEL V

PARAMETER PENGUJIAN HARDDISK

\begin{tabular}{|l|l|l|}
\hline No & Parameter & \multicolumn{1}{|c|}{ Keterangan } \\
\hline 1 & $\begin{array}{l}\text { Disk Random } \\
\text { Seek RW }\end{array}$ & $\begin{array}{l}\text { Pengukuran kemampuan harddisk } \\
\text { dalam pencarian informasi pada file } \\
\text { berukuran besar. }\end{array}$ \\
\hline 2 & $\begin{array}{l}\text { Disk } \\
\text { Sequential } \\
\text { Write }\end{array}$ & $\begin{array}{l}\text { Pengukuran kemampuan harddisk } \\
\text { dalam menulis informasi secara } \\
\text { sequensial. }\end{array}$ \\
\hline 3 & $\begin{array}{l}\text { Disk } \\
\text { Sequential } \\
\text { Read }\end{array}$ & $\begin{array}{l}\text { Pengukuran kemampuan harddisk } \\
\text { dalam membaca informasi secara } \\
\text { sequensial. }\end{array}$ \\
\hline 4 & Disk mark & $\begin{array}{l}\text { Merupakan nilai rata-rata atas hasil } \\
\text { pengukuran seluruh parameter }\end{array}$ \\
\hline
\end{tabular}

Berdasarkan pengujian passmark yang dilakukan sebanyak lima kali terhadap performansi CPU, memory dan harddisk, hasilnya ditunjukkan pada gambar 6 berikut:

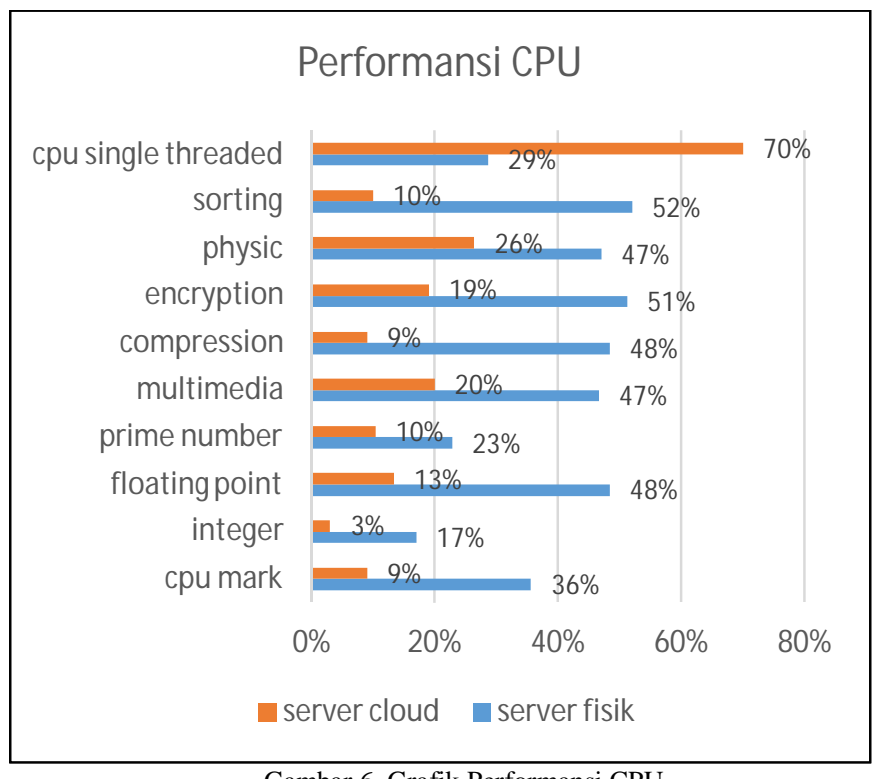

Gambar 6. Grafik Performansi CPU

Sesuai dengan gambar 6, pengujian performansi CPU menunjukkan bahwa pada skenario pengujian pemrosesan single thread, server cloud memberikan hasil yang lebih baik, dengan skor $70 \%$, sedangkan server fisik hanya memperoleh skor $29 \%$. Hal ini disebabkan karena server cloud didukung oleh prosesor intel Xeon E3 seri E3-1225 @3.30 GHz sedangkan server fisik seri E3-1220 @3.10 GHz. pada pengujian proses kalkulasi seperti prime number, floating point, integer serta pengolahan data seperti sorting, physic, encryption, compression, dan multimedia, server fisik menunjukkan performansi yang jauh lebih baik daripada server cloud. Hal ini disebabkan karena prosesor server fisik didukung oleh oleh teknologi quadcore. Sedangkan server cloud hanya single core. Secara keseluruhan skor pengujian (CPU mark) server fisik memproleh hasil yang lebih baik

I K Adi Kurniawan dkk: Analisis Performansi dan Efisiensi ... yaitu 36\% dibandingkan server cloud dengan skor 9\%, hal ini menunjukkan prosesor fisik memberikan performa yang lebih baik untuk pemrosesan multithread, sedangkan server cloud lebih baik untuk skenario single thread.

Pada pengujian performansi memory, server cloud memberikan performansi yang lebih baik pada seluruh skenario pengujian. Nilai keseluruhan menunjukkan server cloud memperoleh skor 50\%, sedangkan server fisik memperoleh skor 35\%. Hal ini disebabkan karena server cloud dibangun diatas virtualisasi berbasis bare-metal hypervisor dimana alokasi resource diatur secara efisien oleh virtual machine manager. Hasil pengujian memory ditampilkan pada gambar 7 .

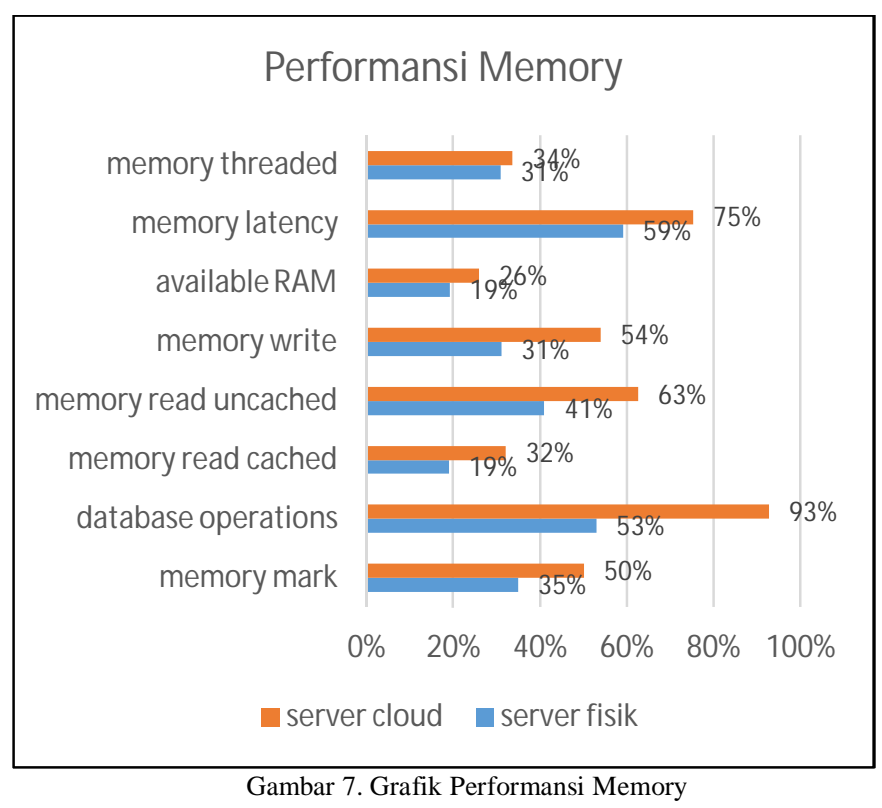

Pengujian performansi harddisk menunjukkan hasil yang berimbang antara server cloud dan server fisik, dimana selisih skor secara keseluruhan tidak signifikan, sebagaimana ditampilkan pada gambar 8 berikut: 


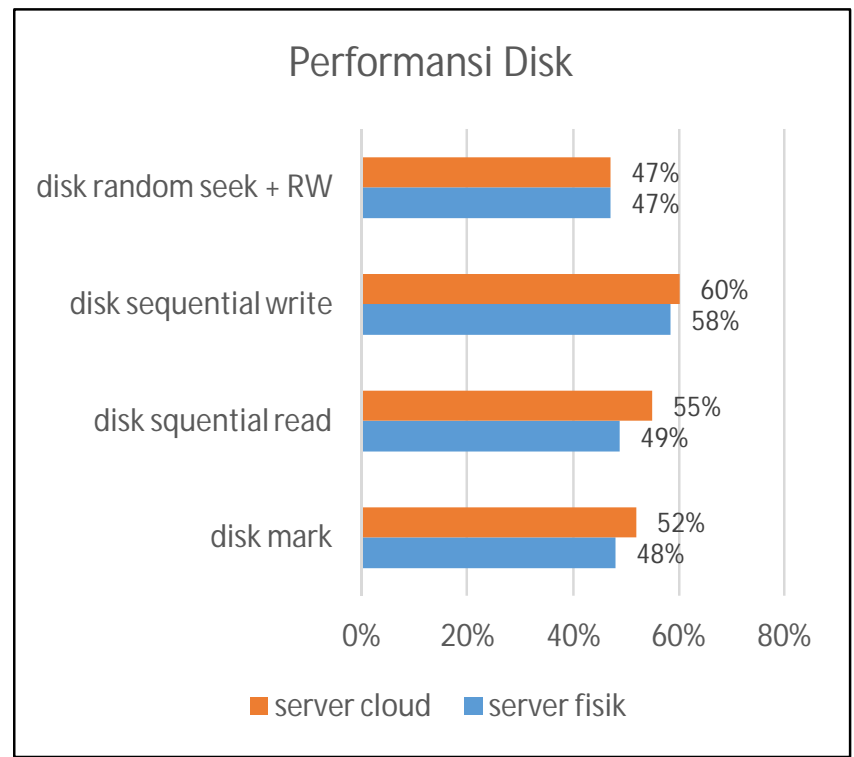

Gambar 8. Grafik Performansi Harddisk

Secara keseluruhan berdasarkan sekenario yang diuji meliputi disk random seek and $R W$, disk sequential write, disk squential read, dan disk mark server cloud sedikit lebih baik dengan skor $52 \%$ dan sedangkan server fisik memperoleh skor $48 \%$.

Pengujian terhadap kecepatan network menggunakan tool iperf dilakukan dengan mengukur kecepatan transmisi data dari client ke server dan sebaliknya.

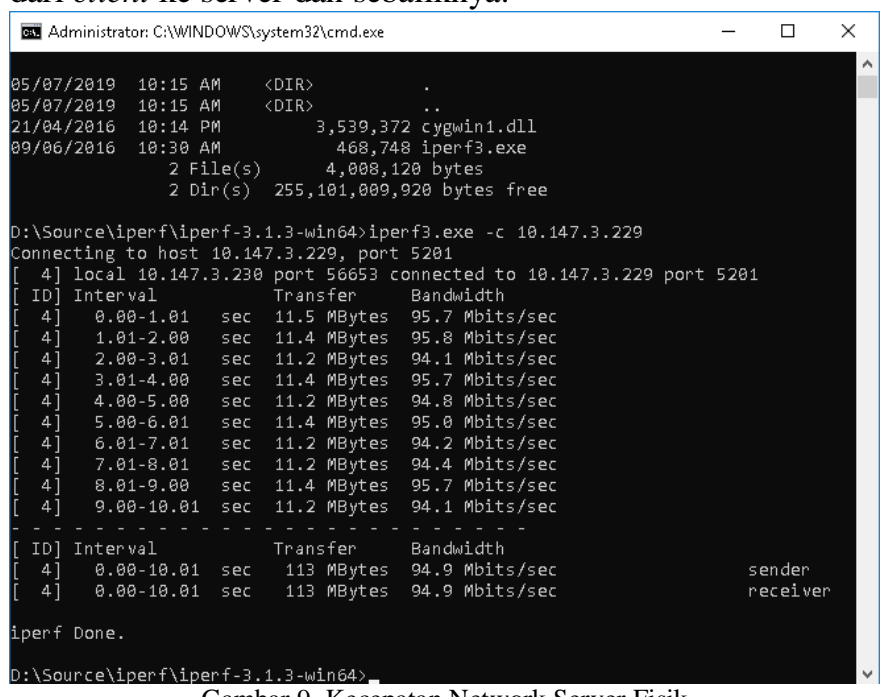

Gambar 9. Kecepatan Network Server Fisik

Dari pengujian transfer data sebesar 113 Mbytes dari client ke server fisik menunjukkan bandwidth yang dicapai adalah 94.9 Mbits/sec baik untuk pada saat send maupun receive sebagaimana ditampilkan pada gambar 9.

Pengujian kecepatan transmisi pada server cloud menunjukkan pada skenario transfer data sebesar 112 MBytes dicapai bandwidth $94.1 \mathrm{Mbits} / \mathrm{sec}$ untuk proses send, sedangkan untuk proses receive dicapai dengan bandwidth 94.0 Mbits/sec seperti ditampilkan pada gambar 10 berikut:

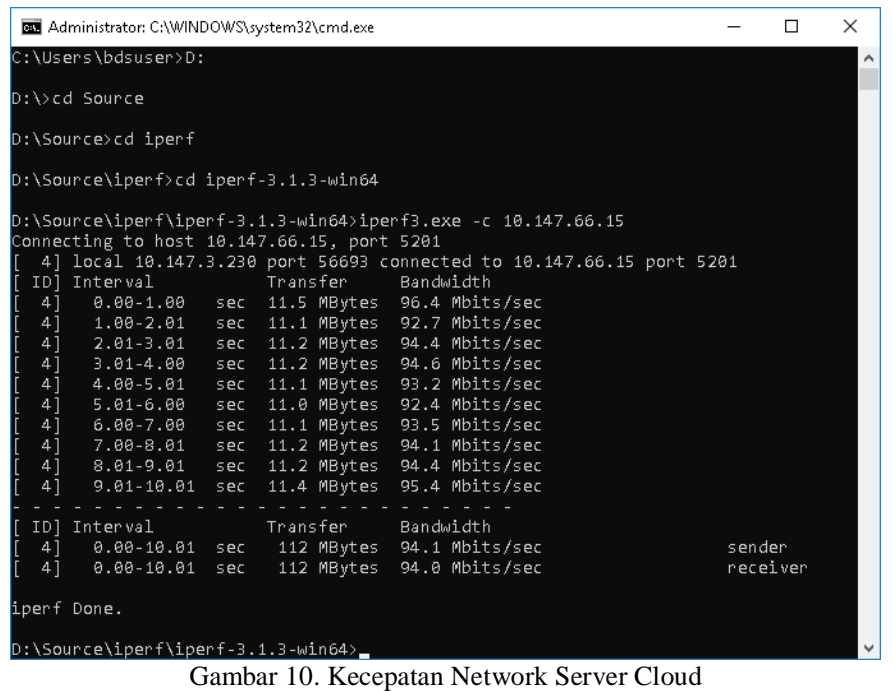

Meskipun secara keseluruhan koneksi dari client ke server fisik lebih cepat, namun perbedaanya dengan kecepatan transmisi dari client ke server cloud tidak signifikan. Hal ini disebabkan karena meskipun client dan server cloud berada pada jaringan lokal yang berbeda, client dan server masih berada dalam satu wide area network yang terhubung melalui koneksi virtual private network.

C. Pengukuran Efisiensi Investasi

Perbandingan efisiensi antara server cloud dengan server fisik mengacu pada biaya deployment yang berdasarkan atas parameter sebagai tabel VI berikut:

TABEL VI

PARAMETER EFISIENSI INVESTASI

\begin{tabular}{|l|l|l|}
\hline Parameter & Server Cloud (Rp) & \multicolumn{1}{|c|}{ Server Fisik(Rp) } \\
\hline $\begin{array}{l}\text { Biaya } \\
\text { perangkat }\end{array}$ & $\begin{array}{l}\text { harga sewa rata-rata } \\
\text { layanan } \\
\text { Infrastructure as a } \\
\text { Service }\end{array}$ & $\begin{array}{l}\text { Harga rata-rata } \\
\text { perangkat server, } \\
\text { dengan usia teknis 5 } \\
\text { tahun }\end{array}$ \\
\hline $\begin{array}{l}\text { Lisensi sistem } \\
\text { operasi }\end{array}$ & $\begin{array}{l}\text { Nihil (sudah } \\
\text { termasuk biaya sewa } \\
\text { perangkat) }\end{array}$ & $\begin{array}{l}\text { Harga rata-rata lisensi } \\
\text { sistem operasi. }\end{array}$ \\
\hline $\begin{array}{l}\text { Biaya } \\
\text { catudaya }\end{array}$ & $\begin{array}{l}\text { Nihil (menjadi } \\
\text { beban penyedia jasa } \\
\text { cloud computing) }\end{array}$ & $\begin{array}{l}\text { Biaya rata-rata } \\
\text { penggunaan listrik } \\
\text { untuk ruang server } \\
\text { selama satu bulan }\end{array}$ \\
\hline Inflasi & $\begin{array}{l}\text { Mengacu pada histori inflasi sejak bulan } \\
\text { Nopember 2017 sampai dengan Juni 2019, } \\
\text { diketahui rata-rata inflasi sebesar 3.13\% }\end{array}$ \\
\hline
\end{tabular}

Berdasarkan parameter pada tabel VI diatas, diperoleh perbandingan efisiensi pada tabel VII sebagai berikut.

TABEL VII

PERBANDINGAN EFISIENSI BIAYA SERVER CLOUd DAN SERVER FISIK

\begin{tabular}{|l|c|c|}
\hline \multicolumn{1}{|c|}{ Parameter } & $\begin{array}{c}\text { Server Cloud } \\
\text { (Rp) }\end{array}$ & $\begin{array}{c}\text { Server Fisik } \\
\text { (Rp) }\end{array}$ \\
\hline Biaya perangkat & $\begin{array}{c}1.948 .482,55 / \\
\text { bulan }\end{array}$ & $\begin{array}{c}10.692 .800 / 5 \\
\text { tahun }\end{array}$ \\
\hline Lisensi sistem & - & 2.085 .000 \\
\hline
\end{tabular}




\begin{tabular}{|l|r|r|}
\hline operasi & - & $1.200 .000 /$ bulan \\
\hline Biaya catudaya & $23.381 .790,6$ & 27.177 .800 \\
\hline $\begin{array}{l}\text { Jumlah biaya dalam } \\
1 \text { tahun }\end{array}$ & 116.908 .953 & 84.777 .800 \\
\hline $\begin{array}{l}\text { Jumlah Biaya dalam } \\
5 \text { tahun }\end{array}$ & 233.817 .906 & $171.330 .434,48$ \\
\hline $\begin{array}{l}\text { Jumlah Biaya dalam } \\
10 \text { tahun (asumsi } \\
\text { inflasi 3.13\%) }\end{array}$ & \multicolumn{2}{|c|}{$(3,796,009.40)$} \\
\hline $\begin{array}{l}\text { Selisih biaya dalam 1 } \\
\text { tahun }\end{array}$ & $23.381 .790,60-27.177 .800=$ \\
\hline $\begin{array}{l}\text { Selisih biaya dalam 5 } \\
\text { tahun }\end{array}$ & $116.908 .953-84.777 .800=$ \\
\hline $\begin{array}{l}\text { Selisih biaya dalam } \\
10 \text { tahun }\end{array}$ & 62.131 .153 \\
\hline
\end{tabular}

Pada tabel VII diatas, biaya perangkat untuk server cloud merupakan harga layanan cloud computing untuk Alibaba Cloud. Demikian pula dengan harga server fisik, merupakan harga rata-rata untuk server fisik standar kantor cabang Bank Mandiri. Sesuai dengan kalkulasi tersebut, server cloud memberikan efisiensi sebesar Rp3,796,009.40 untuk jangka waktu satu tahun. Namun untuk jangka waktu lima tahun, biaya investasi server cloud lebih tinggi Rp32.131.153 daripada server fisik. Sedangkan untuk jangka waktu 10 tahun, biaya investasi server cloud lebih tinggi dengan selisih Rp62.487.471,52 dibandingkan dengan server fisik.

\section{KESIMPULAN}

Berdasarkan implementasi sistem cloud computing diatas, dapat ditarik beberapa kesimpulan sebagai berikut:

1. Arsitektur server fisik yang diterapkan pada sistem perbankan dapat dimigrasi ke arsitektur cloud computing.

2. Metoda ROCCA sebagai salah satu metoda adopsi cloud computing dapat diterapkan dalam migrasi sistem perbankan.

3. Performansi CPU pada server cloud memberikan keunggulan pada proses single thread, namun pada proses multi thread server fisik meberikan performansi lebih baik.

4. Performansi memory server cloud memberikan hasil yang lebih baik karena server cloud berbasis virtualisasi dengan hypervisor (virtual machine manager), sedangkan dari sisi disk I/O tidak menunjukkan perbedaan yang signifikan.

5. Kecepatan transmisi network menunjukkan perbedaan yang tidak signifikan, karena meskipun berbeda jaringan lokal, server cloud dan client masih berada dalam satu wide area network dengan koneksi virtual private network.

6. Efisiensi investasi pada implementasi server cloud hanya terjadi pada jangka waktu satu tahun, sedangkan untuk jangka waktu lima tahun keatas, biaya

I K Adi Kurniawan dkk: Analisis Performansi dan Efisiensi ...

implementasi server cloud lebih tinggi daripada implementasi server fisik.

\section{SARAN}

Saran yang dapat diberikan berdasarkan penelitian ini adalah sebagai berikut:

1. Mempertimbangkan biaya implementasi cloud computing lebih tinggi untuk jangka waktu lebih dari lima tahun, implementasi cloud computing diprioritaskan hanya bagi kantor cabang yang tersebar didaerah pelosok. Sehingga memberikan keunggulan dari sisi biaya maintainance, khususnya biaya akomodasi dan transportasi.

2. Mengembangkan aplikasi BDS berbasis web, sehingga kebutuhan server kantor cabang dapat dieliminasi.

3. Implementasi cloud computing dapat diterapkan untuk project yang bersifat temporary, misalnya program promosi dengan periode kurang dari 6 bulan.

\section{REFERENSI}

[1] C. Setiawan and E. S. Emirsa, "The Policy Analysis of The Pilot Project Priority of Information System Implementation Using Analytical Hierarchy Process," J. Perkomnas, 2014.

[2] A. R. Hakim, "Analisis Perbandingan Sistem Cloud Azure Dan Google Cloud,” J. Nas. Inform. Teknol. Jar., Sep. 2016.

[3] K. Sunami, "Ubiquitous Banks: Cloud Based Design for Core Banking," Int. J. Adv. Res. Comput. Sci., vol. Volume 8, No. 2, March 2017 (Special Issue), 2017.

[4] A. Aljabre, "Cloud Computing for Increased Business Value," 2012.

[5] S. Heripracoyo, "Analisa Studi Literatur Manfaat Implementasi Komputasi Awan Untuk Perusahaan,” 2014.

[6] K. Rathod, "Cloud Computing - Key Pillar For Digital India," Int. J. Inf. Sci. Tech. IJIST, vol. Vol.6, no. No.1/2, 2016.

[7] S. K. Sharma, A. H. Al-Badi, S. M. Govindaluri, and M. H. AlKharusi, "Predicting Motivators Of Cloud Computing Adoption: A Developing Country Perspective," Comput. Hum. Behav., vol. 62, 2016.

[8] P. Rieger, H. Gewald, and B. Schumacher, "Cloud-Computing in Banking Influential Factors, Benefits and Risks from a Decision Makers Perspective." Researchgate, 2013.

[9] B. Nedelcu, M.-E. Stefanet, I.-F. Tamasescu, S.-E. Tintoiu, and A. Vezeanu, "Cloud Computing and its Challenges and Benefits in the Bank System," Database Syst. J., vol. VI, no. 1, 2015.

[10] C. Agre, "Implementation of a Cloud in Banking Sector," 2015.

[11] P. Goel, "Cloud Computing- Banking on the Cloud," 2013.

[12] A. Irfan and P. I. Santosa, "Adopsi Cloud Computing Pada UKM Di Indonesia," 2015.

[13] A. Apostu, E. Rednic, and F. Puican, "Modeling Cloud architecture in banking systems," elsevier, 2012.

[14] S. Goyal, "Public vs Private vs Hybrid vs Community - Cloud Computing: A Critical Review," IJ Comput. Netw. Inf. Secur., 2014.

[15] V. Chang, R. J. Walters, and G. B. Wills, "Organisational Sustainability Modelling -anemerging service and analytics model for evaluating Cloud Computing adoptionwith two case studies," Int. J. Inf. Manag., vol. Vol. 36, no. 1, pp. 167-179, 2016.

[16] D. Ray, "Cloud Adoption Decisions: Benefitting from an Integrated Perspective," TheElectronic J. Inf. Syst. Eval., vol. Vol. 19, no. No.1, 2016.

[17] F. Shimba, "Cloud Computing :Strategies for Cloud Computing Adoption," 2010.

[18] M. Suprayogi, "Implementasi Cloud Computing Menggunakan Model Adopsi Roadmap For Cloud Computing Adoption (ROCCA) Pada

p-ISSN:1693 - 2951; e-ISSN: 2503-2372 
Institusi Pendidikan (Studi Kasus Universitas Semarang)," 2014, 2014.

[19] J. Hwang, S. Zeng, F. y Wu, and T. Wood, "A Component-Based Performance Comparison of Four Hypervisors," 2013.
[20] R. Kumar and S. Charu, "An Importance of Using Virtualization Technology in Cloud Computing," Glob. J. Comput. Technol., vol. Vol. 1, no. No. 2, 2015.

[21] H. Fayyad-Kazan, L. Perneel, and M. Timmerman, "Benchmarking the Performance of Microsoft Hyper-V server, VMware ESXi and Xen Hypervisors," 2013. 